\title{
Economic Space United Accounting System - The Conceptual Direction of Regional Economy's Development
}

\author{
Yuri I. Sigidov \\ Kuban State Agrarian University, \\ Department of Theoretical Accounting \\ Krasnodar, Russia \\ tbu_kuban@mail.ru
}

\author{
Sergei P. Pershin \\ Kuban State Agrarian University, \\ Department of Theoretical Accounting \\ Krasnodar, Russia \\ PershinSP@mail.ru
}

\begin{abstract}
Contemporary economic relations system needs applying modern tools for regulating and managing economic relations. Numerous researches in the accounting sphere have determined such a conceptual direction as unification of economic entities' accounting environment in the framework of a region's united and automated accounting system. Such a system implies each economic entity's and management body's role, rights and responsibilities. The article presents the notion of an "accounting agent", which is an entity, fulfilling certain functions on keeping the account of business operation items, whereas while interacting with contractors, an "accounting agent" keeps the account of small business entities. Such a system proved to be effective in the opportunity to provide economic relation transparency, to engage more participants in the economy, to form effective introduction and improvement of the economic activity regulatory procedures, to ensure simplicity and each entity's accounting data sufficient analogy.
\end{abstract}

Keywords - accounting, united accounting system, accounting agent, control, management, automation, regional economy

\section{Introduction}

Economic relations are a complex system of mutually influencing factors. Such a system's functioning principles are determined by those conditions, which have long been under study. Each phenomenon, dependence. Result can be predicted basing on a person's present knowledge. This person can define economic relations' directions according to his ther interests and available tools. Thus, we consider this article's topic urgent.

The goal of this study is to substantiate the need to create a united economic space accounting system for providing economic entities' economic relations' transparency.

The region's economic relations total determines the integral financial system's functioning. According to International Monetary Fund "a financial system consists of institutional units and markets, which generally interact in a complex way, in order to raise funds for investments and providing the resources, including payment systems, for financing the business [2].

Many works on studying the complex financial system's determination and economic relation have been published, among them are the works by A. Dadasheva, Z. Bodie, D. Vinogradova, G. Kleiner, D. Tyutina and others. L. Igonina pointed out that the economic relations' development facilitated the scientific community's interest to analyzing these relations and creating new conceptions, which explain this notions essence and role in the economy [6].

The scientific works in the economic relations financial systems development sphere have made a significant contribution to the development of issues, being under study, however, some aspects, the formation of tools for introducing a united accounting system into the regions' practice in particular, have determined this article's direction, goals and objectives.

\section{MATERIALS AND METHODS (MODEL)}

This research's methodological and theoretical basis have included the works of local and foreign economists in the economic relations and financial systems' development, Russian Federation and Krasnodar Krai's legal and normative acts.

The authors have used the following methods for achieving the goals of this study: monographic method, observation, generalization, systematization, analysis and synthesis, modelling and etc..

Krasnodar Krai's Federal State Statistics Service, Russian Federation Tax Service and commercial organizations' registers and account have served as the information base for the current study.

\section{Results and Discussion}

The need for a new automated accounting system. In order for the financial system to develop progressively and intensively, we need participants, i.e. economic entities, oriented at achieving good results and being able to have influence, using personal and professional qualities. The problems arise because these economic entities are sometimes oriented not at achieving results, strategically important for economic relations and society, but at meeting their own demands at the expense of the afore-mentioned goals. Organizational, political and legal gaps in the economic 
relations sphere, which was established in the 1990s, led to unfavourable consequences, which didn't meet the society and state's demands, provoked social tension and economic crime rate rise.

Drastic economy's reformation, which has not always been reasonable, has led to the economic crime rise [12]. Ye. Kondrat pointed out that when there are certain conditions, criminal economy turns out to be the dominating economic relations core sector, determining the whole socio-economic systems' development direction and creating conditions for its functioning. State institutions, authority and management bodies, democratic institutions, controlling and law enforcement bodies systems are subject to criminalization in the most complicated cases. We know the cases, when criminal economic activity is the international specialization core, determining the state's place in international division of labour. Concrete criminal economy socio-economic consequences are as diverse as criminal economic activity is. [7].

Special skills and knowledge are necessary for effective economic management. In the first case, certain results' achievement is achieved by educating, informing and creating special conditions, which exclude economic relations rules misuse with the aim of gaining personal advantage. In the second case, education, system professional training, skills development and ability to study are important for being competitive in the economic environment. Failures occur in both cases, what evolves economic relations system's problems and difficulties. The stabilization of the above-mentioned effective economy's directions should be fulfilled with the use of modern means and methods, which exclude negative external impact and the administering party's excess.

An accounting system can become an important stabilization tool, which can be an objective administrator and economic relations tool, oriented at the preplanned result and controlled by the public opinion. [3]. Such a system is intended to fulfil an auditor's functions. I. Bogataya and A. Kizilov emphasize that audit evolution has led to the increased demand for auditing the business, which is aimed at assessing the economic activity's development prospects in a complex way and at analyzing the risks of bankruptcy [5]. We consider an independent automated accounting system to be an effective administering tool, whicl could allow to accumulate information on the financial-economic state of an enormous number of economic relations entities, by means of a certain algorithm which form, generalizes, analyzes and audits the data for certain users categories. The scientific interpretation of such an opinion demanded studying modern economy's functioning conditions and tasks.

Small and medium business development goal. The application of the afore-mentioned accounting system is aimed at having positive economic effect, evolved by attracting new participants to the economy. Regional business environment development implies transparent competition, where each participant participates in the economic turnover on equal terms and strives at meeting the goals by getting the advantages, based on their goods and service's features, work speed and so on. There cases when the economy's participants try to develop by misusing their taxation rights, thus pretending to be small businesses and getting special perks for it [10].

The experience of being this or that market's participant is the advantage in comparison with new market participants. This experienced participants' advantage implies the opportunity to merge new sales markets, thus occupying leading positions and becoming monopolists. Modern practice has shown that experienced participants long for gaining unjustified tax and economic value, thus providing themselves with the necessary profitability rate. Here we mean the misuses of the tax and civil law.

Dallago B. uses the term "irregulated economy" for denoting shadow economic processes. Under this term he implies the economic agents' activity, which doesn't submit to regulatory rules and laws or is hidden from the state management and control bodies [1].

It is very hard for new participants to work in the framework of such irregulated economy, consequently, they need help. It is worth noting that we imply not direct help but certain favourable conditions, based on legal requirements to organizing an entity's the economic activity.

Completeness and analyticity of the accounting data. Another important issue in the development of the country's economy with the use of modern accounting procedures is the provision of a simple and at the same time qualitative accounting of all facts of economic life. A business manager should not be distracted by the registration difficulties, compiling and submitting reporting information. State bodies' controlling measures should not distract the entrepreneur from the implementing of the goals set, aggravate the economic situation of the audited entity by setting out a whole lot of requirements for supervising the control activity.

If a state body needs this or that information, it must provide a mechanism for forming and getting it at a convenient time and in a convenient form. It is unacceptable to entrust the manager with responsibility for meeting the information demands of the controlling body.

In this regard, we consider it reasonable to organize an accounting process using modern accounting automated technologies, in which accounting data is generated at the time of the economic life fact fulfillment. This is done by producing the accounts in a united accounting system [9]. Such a system is a reflection of a united economic space, where each participant is the subject of forming an account on the economic life fact.

In such an accounting system the interaction between the participants, regardless of their status and participation character, is carried out using automated technologies and reflecting the records on the relevant accounting objects' mutual change. It becomes possible to transfer a significant part of the accounting work to accounting agents. Which are: 1) large business managers who apply the general taxation regime and are obliged to maintain full accounting and tax records, 2) various state bodies, services, institutions, organizations authorized in a particular financial control area, state registration, of accounting databases maintenance. In such a situation, small businesses get the opportunity not 
to keep the accounting of a large number of economic life facts occurring with their accounting objects.

Rulemaking implementation. There are problems in the modern economy, connected with prompt and proper perception of newly introduced and (or) amended provisions of regulatory acts. In the conditions of the suggested automated accounting system's work, the introduction of requirements to organizing and implementing the state policy in the sphere of economy and other state regulation related areas of is carried out by creating, changing the accounting and registration algorithms.

The economic life facts made by an entrepreneur must be reflected in a united accounting system. During its activity process the economic entity should follow the established program algorithm, reflecting the actual characteristics of the economic life facts. The accounting system can suggest ways and opportunities to implement the economic program independently, involving participants in the economic turnover. Here, a participant does not form the economic program, using his knowledge, experience and cognitive and organizational skills and economic ties already set, but the program suggests participation in the economic project according to the established rules. There is no need to train specially to fulfill the implementation requirements, for example, export, import operations, public procurement work, subsidized economic projects work.

Economic ties implementation transparency becomes the protection from unfair competition becomes, based on legal production resources, registered in the accounting system. The decisions of the administrative state or other body become transparent and available to assess by any potential participant or interested person. The formation of primary accounting documentation, accounting registers, accounting data is carried out automatically. The participant who entered an economic project implements the economic life facts, the performance of which is attributed to his responsibility.

Excess of rights and misuses in the economic environment. The proposed automated accounting system becomes a kind of tool for cleaning up the business environment from fictitious organizations and individual entrepreneurs registered according to the established procedure allegedly for carrying out economic activities, but in fact suggesting the requisites of such entities for performing imaginary, fake transactions. Such entities form the shadow economy space, including the cyberspace.

In this case the shadow economy is a goods and services market for committing of cybercrimes, as well as for selling stolen goods and information. It is a "united economic space" for producers, sellers, suppliers, scammers and customers and allows criminals to organize their activity [7].

Each economic entity reflects its production and other economic capacities in the proposed united accounting system for the united economic space. In a generalized form, this is shown in the balance sheet. At the same time, each of its articles is correlated with the counterparty's assets formation source. In each case, the asset is produced, imported, acquired and originated in a different way. And in each case there is a responsible person - the same participant in the united economic space system. The responsibility for such a source can not be entrusted on an undetermined subject or an unknown origin. In order to enter the economic space system, it is necessary to register the assets and justify the sources of their formation, linking them with specific economic entities.

The access to registration actions is done by connecting to the personal account of the economic relations participant using automated information technologies and is available from any portable or stationary device. System's central administrator protects and secures the connection. Such can be an authorized state body. It is worth noting the opinion of $\mathrm{P}$. Orekhovsky, who defined a strict criterion for referring to the shadow economy, which is the absence of transactions state registration [4]. In the considered environment of a united automated accounting space, such a criterion becomes the leading one.

The functioning of a single automated accounting system of the economic space assumes a conceptual transformation of accounting principles. Here, each participant in economic relations presents itself as an element of a single system, initially involved in a unified balance of assets, sources of their formation and obligations. Credit organizations and other entities authorized to provide financial settlements become members of the system with the relevant status. Access to their services is carried out solely on the basis of the facts of economic life reflected in the single accounting system [11]. An order to make payment on settlement accounts, for example, a buyer and a seller, is made by forming an appropriate account connecting the credentials of the cash balances on the payer's account and the details of the beneficiary's account. In a single accounting system there is registration of the transfer of an asset from one subject to another.

The functioning of a united automated accounting system of the economic space assumes a conceptual transformation of accounting principles. Here, each economic relations participant presents itself as an element of a united system, initially involved in a unified assets balance, sources of their formation and obligations. Credit organizations and other entities authorized to provide financial arrangements become members of the system with a relevant status. Access to their services is carried out solely on the basis of the economic life facts reflected in the united accounting system [11]. A payment order on operating accounts of a buyer and a seller, for example, is made by forming an appropriate account, connecting the credentials of the cash balances on the payer's account and the details of the beneficiary's account. In a united accounting system there is registration of the transfer of an asset from one subject to another.

Potential participants must be ready to work in a united automated economic space's new accounting system. We mean getting basic knowledge on the system of secondary and higher vocational education. In this regard, endless changes in the business order (civil and tax legislation, the development of systems of economic relations in certain sectors of the economy) get a new conceptual basis for implementation. It is unnecessary to seek a thorough study of the established, often rather complicated, procedures issued by professional regulatory bodies, to involve people which these newly 
introduced or amended procedures are oriented at and to practice of reading the text of the law and understanding it basing on the author's intent. The user of the normative act should understand its main provisions flowing out of the established principles of the implemented and (or) order being changed and should understand and accept the requirements and goals which the legislator is trying to achieve.

In order to implement the provisions of regulatory legal acts, it is enough to elaborate the procedure of using them in a united accounting system that ensures the registration of economic life facts in a given algorithm. The proposed procedure makes allows to exclude ambiguous interpretation of law provisions and its formal use. For example, at present, it is required to use the procurement schedule, a specific list of documents reflecting the activities of the tender participant, the results of market valuation and other documents and information for government needs purchasing. In a united automated accounting system, participation in a tender for according to a supplier is implemented by the indication of necessary information, the submission of documentary grounds, formed mainly basing on the data from a united accounting system, by reflecting the sequence of acts, according to the algorithm set.

The tender procedure results are presented in the same accounting system. The person, organizing the competition, according to the information provided, is able to make a decision regarding the financial stability and production capabilities of the supplier, its business reputation, the signs of negligence. A potential supplier sees a step-by-step instruction, established requirements for the tender participant. The suppliers accreditation is developed by the administrator or other authorized body, if necessary.

The suggested system allows conducting an unprecedented monitoring of the assets movement, economic entities liabilities, receiving operational information in order to control the economic life facts. The participant of such an automated accounting space demonstrates his property status, solvency level, and later - the experience and authority gained basing on the counterparts and experts' feedback [11].

The role of the administrative body in the functioning of this system is important, and implies the existence and active participation of a professional expert community. The latter are large economic figures who have sufficient experience in this or that field of activity and are able to give an objective assessment of the essence and results of an individual subject's activity, either by a special request from the supervisory or administrative body, or in the course of systematic monitoring[3].

The system allows to illustrate the content of economic relations, the reality of economic activity and excludes (minimizes) the commission of imaginary, fake transactions and fraud. For people who are not afraid of the responsibility for committing illegal actions, dummy individuals and organizations, it becomes unacceptable to operate under the supervision of the mutual linking of information on economic life facts that ensures the collection of information regarding real beneficiaries. The latter can be not only legal, but also an individual (a group of individuals), regardless of his official position.
At the same time, the access rights of administrating and controlling subjects of a united economic space implement ensuring security of banking, tax and commercial secrets.

\section{Conclusion}

Achieving the most important effect related to the settlement of economic relations on the regional level, involvement of new participants, simplification of the accounting and reporting procedures, provision of professional administration of the united economic space becomes the key factor in the of the modern regional economy's development.

\section{Acknowledgment}

The research was carried out with the Russian Foundation for Basic Research and Krasnodar Krai support in the framework of the scientific project № 1646-230131

\section{References}

[1]. Dallago B. (1994) The irregular economy in transition: features, measurment and scope // Output Decline in Eastern Europe: Unavoidable, Extertal influence or Homemade? / Ed. by R.Z. Holzman [et al.]. IIASA, Luxemburg.

[2]. IMF, 2004, Compilation Guide on Financial Soundness Indicators, IMF, Washington DC, para. 2.2.

[3]. Glushchenko A.V., Kucherova Y.P., Yarkova I.V. Ensuring an Agricultural Holding's Economic Security by Means of Sustainable Development Strategies in Terms of Global Crisis Management // Revista ESPACIOS. 2018. Vol. 39(9).

[4]. Barsukova S.Yu. Informal economy: structure and functional specificity of segments: Abstract. dis. ... Doctor of Social Sciences. M., 2004.

[5]. Bogataya I.N., Kizilov A.N. The study of the business audit essence and the methodological approach to structuring its objects / / Modern problems of science and education. 2015. №. 1-1. P. 549. URL: https://scienceeducation.ru/ru/article/view?id=17812.

[6]. Igonina L.L. Financial system and economic development: a monography. M .: Rusains, 2016. $140 \mathrm{p}$.

[7]. Kondrat E.N. Violations in the financial sphere of Russia. Threats to financial security and ways of counteraction // Kondrat E.N. - " Юстицинформ ", 2014.

[8]. Official description of G Data for 2009: "The shadow economy". URL: http://www.gdatasoftware.com/uploads/media/Whi tepaper_Underground_Economy_8_2009_GB.pdf

[9]. Pershin S.P. Accounting in real time - reality and perspectives / S.P. Pershin // In the collection of papers: Modern economy: problems, perspectives, information support: materials of the VI 
international scientific conference dedicated to the 95th anniversary of the Kuban State University of Management and the 15th anniversary of the Accounting Theory Department. 2017. P. 145-148.

[10]. Pershin S.P. Administrative resource in a united accounting space as a means of ensuring economic growth / S.P. Pershin, V.D. Mozhegova // Polytopical network electronic scientific journal of Kuban State Agrarian University (Scientific Journal of KubSAU) [Electronic resource]. Krasnodar: KubGAU, 2016. - №04 (118). Pp. 563 - 583. - IDA [article ID]: 1181604031. Access: http://ej.kubagro.ru/2016/04/pdf/31.pdf.
[11]. Pershin S.P. United accounting space and accounting agents as accounting development techniques / S.P. Pershin, T.V. Posokhova // The Political Network Electronic Scientific Journal of the Kuban State Agrarian University (Scientific Journal KubSAU) [Electronic resource]. Krasnodar: KubGAU, 2015. - №08 (112). P. 644 660. - IDA [article ID]: 1121508047. - Access http://ej.kubagro.ru/2015/08/pdf/47.pdf.

[12]. Fedorov A.Yu. Legal protection of corporate relations: actual problems, counteraction to modern criminal threats, foreign experience: scientific-practical. textbook. M., 2012. 